\title{
Entrepreneurship and Innovation in the Polish Industry
}

\author{
JAN ZWOLAK \\ Faculty of Economic Sciences \\ Pope John Paul II State School of Higher Education in Biała Podlaska \\ 21-500 Biała Podlaska, ul. Sidorska 95/97 \\ POLAND
}

\begin{abstract}
Entrepreneurship is a process in which goals or tasks are set at one's own initiative, whereby no efforts are spared to ensure their efficient and effective implementation. The concept of entrepreneurship is associated with innovation as entailing ongoing research and the introduction of rational changes and novel ideas. The aim of the research is to determine the regression interdependencies between the number of enterprises (entrepreneurship) and process and product innovation expenditure (innovators' activity) and the number of inventions (inventors' activity), and in the second regression model: also the number of enterprises (entrepreneurship) and process and product innovative expenditure (innovators' activity) and the number of patents (inventors' activities) generated within the Polish industry in the years 2015-2017. The hypothesis is that patents (inventors' activities) get reinforced with process and product innovation expenditures (innovators' activities) employed in the process of growth of the number of enterprises (entrepreneurship) in industry, as well as the overall efficiency of expenditures and technologies (patents) in the Polish industry over the course of the researched years. Conducted studies have confirmed the above hypothesis. In addition, the research carried out has shown that patents (inventors 'activities) have supplemented the share (elasticity) of process and product innovation (innovators' activities) by $10 \%$ in the increase in the number of enterprises (entrepreneurship) as observed in industry. This share is transferred from the supply element to that of demand.
\end{abstract}

Key-Words:- entrepreneurship, process and product innovative expenditure, inventions and patents, growth model, power regression model, industry, Poland.

Received: May 18, 2021. Revised: December 19, 2021. Accepted: January 5, 2022. Published: January 7, 2022.

\section{Introduction}

Readiness to undertake innovation in production or services is related to its propensity. It is consequent to a conscious pursuit of changes in the production process or concerning the nature of the product (active innovation), while it may also be forced by the environment or market competition (passive innovation).

Propensity to innovation is also associated with readiness to accept risks and tensions that accompany the course of process or product changes, with the simultaneous need to undertake investments, and to introduce a product or service onto the market [1]. Propensity to innovation is an indispensable, yet insufficient condition for innovation. It depends on many factors, such as the size of the enterprise, the level of competition on the market and the structure of economy organization.

The transfer of innovation is related to the process as a result of which the range of invention implementation (patent) in the economy is expanding. We are rather dealing here with a diffusion of innovation. It involves extending the use of innovation within one enterprise (the use of an invention in an enterprise). The nature of this application can be gradual and it may occur between enterprises representing a similar type of production or services rendered (horizontal transfer) or between different types of production or services rendered (diagonal transfer). The transfer of innovation can be measured with the number of enterprises (entrepreneurship) that have applied the new invention (patent), the value of production or innovative services in absolute amounts, based on the new invention, or the share of the value of production or innovative services in production or in services of a given type. These categories, such as enterprise (entrepreneurship), process and product innovation (activities of innovators) and inventions (and patents) (activities of inventors) are the subject of the study in this article.

The above-mentioned issues have not been sufficiently developed in the understanding of relationships (relations) occurring between these categories in the industry of given economies at the macroeconomic level. The presentation of this research constitutes a contribution to the development of the theory (growth model) of 
regression interdependencies occurring between these categories in the Polish industry.

The aim of the research is to determine the regression relationships between the number of enterprises (entrepreneurship) and the expenditure on process and product innovation (innovators' activity) as well as the number of inventions (inventors' activity), and in the second regression model: also between the number of enterprises (entrepreneurship) and expenditure on process and product innovation (innovators' activity) and the number of patents (inventors' activities) in the industry in Poland in the years 2015-2017.

Constituting the foundation of the research is the hypothesis that patents (inventors' activities) are reinforced with the expenditures on process and product innovation (activities of innovators) in the course of the process of increasing the number of enterprises (entrepreneurship) in industry and with the overall efficiency of inputs and technologies (patents) observed in the Polish industry in the researched years.

Section 2 presents a selection of theoretical and empirical literature. Section 3 describes the applied methodology. Section 4 contains variable parameters and their respective analysis. Section 5 presents the results and the discussion. Finally, section 6 features the final conclusion.

\section{Literature Review}

The research conducted by [2] Hughes and Mina (2010) indicates that patent in enterprises is an increasingly important factor in the environment of financial support. Patents also have been proven to limit competitive access [3]. In a highly competitive environment, a patent plays the role of a strategic instrument [4]. In order to capitalise on the higher value, competitive markets are needed to develop the dynamic capability of enterprises, which is what innovation provides [5]. The patent serves the markets of highly profitable economies [6]. The quality of patents itself ought to be patented (highquality patents). This, in turn, implicates the increase in the responsibility for creating new products and new ventures [7].

The information on the grant should be known prior to the patent being issued [8]. At the same time, business methods should be separated from patents [9].

Innovations in business models are also distinguished: $R \& D$ is separated from the production in enterprises [10]. In order to stimulate the development of business methods, existing patents are reviewed with respect to the possible improvements that can be effectuated in relation thereto [11]. Patents serve the desired purpose of catalysing innovation [12]. Product innovation leads to product differentiation (range) and to the introduction of a variety of goods and services [13]. A patent as a source of innovation constitutes the development of the technology market for the benefit of the national economy. A significant proportion of patents on the market serve to increase the benefits of this market [14]. Market motivation plays an important role in shaping the investment in new technologies [15].

Patents promote innovation. This is the exclusive right to implement innovation [16]. The level of activity of a given idea shifts the technological environment. At the same time, the asymmetry of knowledge can be better placed [17].

Wherever legal coercion limits capacity and patent law could be adapted, there is one common feature applicable to those two circumstances - the incentive approach [18]. The reallocation of activities to sectors where an intense increase in knowledge is noted causes changes in the structure. The same is applicable to the sector for activities showing a greater demand for knowledge [19]. The horizontal transfer of innovation affects all sectors to the same extent. The result is that no new sectors are created. A new sector springs up wherever the level of high technologies increases, thus creating a new direction of growth [20]. Owning technology allows competitive entry onto a new market segment or an entry onto an entirely new market [21]. New individuals can strengthen the competition and improve long-term performance with the help of Schumpeter competition [22, 23].

In most cases, launching an activity is facilitated by patents as a key collective property and entrepreneurship development tool. The patent business plan helps focus on the technology base, effective management, information protection and an efficient task delivery [24]. R\&D expenditure management increases the patent-measured efficiency [25]. All models suggest a directional role for $R \& D$ spending (elasticity 0.37-0.48) [26]. Patents also increment the value of the enterprise, either through their sales or by means of entrepreneurial growth [27]. The increase in the number of patents in an enterprise is associated with its higher market price as a signal of the quality of the enterprise in question [28]. It serves as a protection mechanism for the intellectual capital of an enterprise; for the most part, it functions as a patent system [29]. Useful models indicate irrelevant patents and an alternative short-time protection of this invention, as well as the lower cost 
of its protection [30]. This leads to harmonisation of growth and ensures positive structural changes in industry [31]. The industry has the greatest potential for implementing innovations. It boosts the efficiency of innovation and integrates the remaining sectors of the economy. It determines the implementation of innovations therein and creates an environment of innovation application [32].

The goal of business incubators is entrepreneurship, creative work, commercialisation of research and undertaking profitable projects [33].The actual implementation of technologies (patents) does not only initiate business (entrepreneurship) but it also significantly contributes to the national economic growth [34]. Competition can affect the implementation of various technical patent standards within the same industry [35]. Joining patents for technology substitution can limit competition and discourage innovation [36]. Combined innovation adopts a central position in the economic growth [37]. Small countries (like, for instance, Estonia) should increase its public R\&D and innovation expenditure, as well as its spending on public science and technology universities, together with their international patenting [38].
Intellectual property theory explains that patents protect the newly created knowledge. From an economic point of view, it follows that innovation implies new ways of undertaking entrepreneurship. On the other hand, the theory of excessive entrepreneurship indicates the need for the existence of generated knowledge to ensure the growth in entrepreneurship within newly created enterprises, since a start-up is favoured by new investments [39]. The comparative advantage is correlated with industry technologies [40]. The praxeological model shows that patents understood as a patent system are necessary for the indispensable for innovation. However, it does not explain the complex relationship of the patent system with science and innovation. Every model - not only the praxeological one - is simplified and requires empirical verification. An extended patent renewal model can be used to understand the empirical regularity of the data [41].

\section{Research Methodology}

The model whose source is $R \& D$ and the patent system is referred to as the supply model. It is also a curvilinear model of the innovation process (Figure $1)$ :

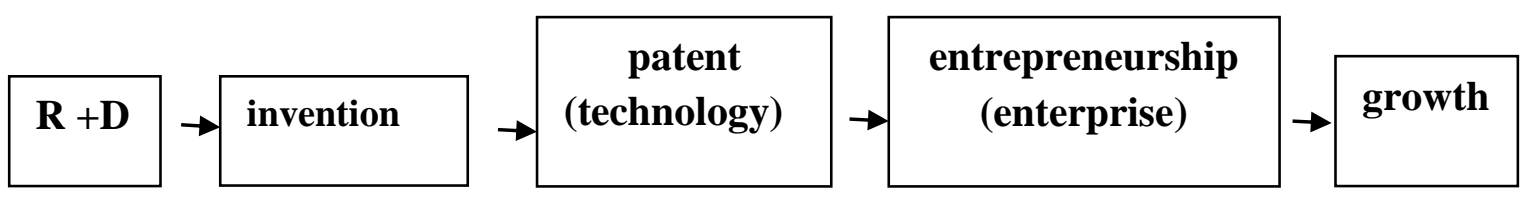

Fig. 1: Elements of the innovation process growth model

In this model, one can distinguish the endogenous growth model due to the role it plays in the field of innovation. We can distinguish the activity of the inventor (patent) and, separately, the activity of the innovator [42]. We are dealing here with a two-way relationship between $\mathrm{R} \& \mathrm{D}$ expenditure and innovation. There is also the interdependency between innovation and economic growth. Each of those three variables has the potential to function separately in a relationship [43]. The growth model of entrepreneurship (enterprises) is a function of inventions (patents) (inventors' activities) and innovative process and product expenditures (innovators' activities). It follows that the subject of the study is the growth model (figure 2).

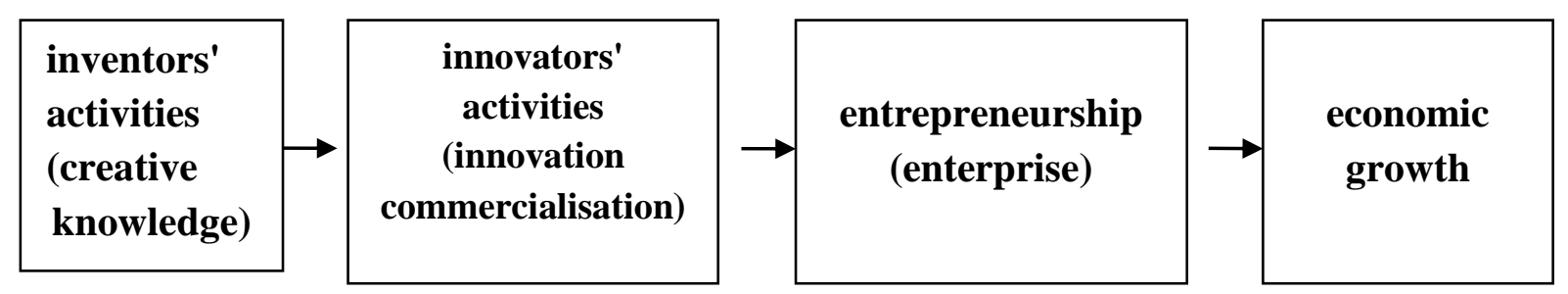

Fig. 2: Elements of the economic growth model with the separation of the activities performed by inventors and innovators 
This model provides a general model for the endogenous growth of balance that separates the invention from innovation, whereby the excess of knowledge is estimated simultaneously between these two activities. The economic growth provides a dynamic complement to these activities. The process of economic growth serves to mutually enhance the separate activities and knowledge as well as its commercialisation.

The theory of entrepreneurship of the saving formula indicates that the more the indicator of cost intensity of the sold value of industry decreases, the stronger the increase of the cost advantage of innovative value sold. This indicates entrepreneurial rationalisation of the composition of the elements of the economic system or the industry sector in question. This rationalisation is the primary phase relative to the main phase of entrepreneurial and economic activity. The growth rate [44] within the extreme range, within the scope of process and product innovation expenditure as well as the spending employed for inventions and patents per enterprise, indicates the degree of activity of innovation commercialisation and the degree to which the knowledge necessitated by innovation is created within the industry.

The comparison of the marginal categories with the average values in individual examinations of independent variables, and their respective correlation, indicates the possibilities of their balancing in conducted entrepreneurship within industry. This constitutes the economic value of entrepreneurship [45].

\section{Data and Empirical Analysis}

The highest internal variability is shown by the set of enterprises in industry in the years 2015-2017 (95\%). The average set of enterprises is over 1.7 times smaller than the centre number of their range $0.5\left(\mathrm{x}_{\mathrm{n}}+\mathrm{x}_{1}\right)($ Table 1$)$.

Process and product innovation outlays show a lower internal variability in the set by over 10 percentage points than the internal variability of industrial enterprises. And their mean of the set is over 1.7 times lesser than the value of the mid range. It can be assumed that the distributions of the compared sets are similar.

On the other hand, the set of the number of inventions in the analysed years indicates that the variability is lower by over 16 percentage points compared to the set of the number of enterprises in industry. The average of the set is over 1.9 times smaller than the number of the centre range of inventions.

In contrast, the average of patents is 2.3 times smaller than the number of their centre range. The internal variability of the set of the number of patents is similar to the set of the number of industrial enterprises. The patent variable and the enterprise variable have similar set distributions.

The chronologically discussed variables shown in Table 1 indicate a decrease in the mean in each of the sets of variables relative to their centre range. This relationship is a common feature of the studied variables.

Table 1. Parameters of the features of innovative variables within the industry in Poland in the years 2015-2017

\begin{tabular}{|l|l|c|c|c|c|c|}
\hline Item & \multicolumn{1}{|c|}{ Specification } & Symbol & $\begin{array}{c}\text { Measurement } \\
\text { unit }\end{array}$ & $\begin{array}{c}\text { Arithmetic } \\
\text { average }\end{array}$ & $\begin{array}{c}\text { Range } \\
\text { min. - max. }\end{array}$ & $\begin{array}{c}\text { Coefficient of } \\
\text { variation \% }\end{array}$ \\
\hline 1. & Number of enterprises & $\mathrm{Y} 1$ & number & 7418.0 & $1031.3-24800.8$ & 95 \\
\hline 2. & $\begin{array}{l}\text { Process and product } \\
\text { innovation outlays }\end{array}$ & $\mathrm{X} 1$ & million PLN & 1496.7 & $251.6-4944.5$ & 84.7 \\
\hline 3. & Number of inventions & $\mathrm{X} 2$ & number & 267.9 & $59.0-983.0$ & 78.8 \\
\hline 4. & Number of patents & $\mathrm{X} 3$ & number & 177.3 & $21.0-811.0$ & 93.3 \\
\hline
\end{tabular}

Source: Statistical yearbook of voivodships. Central Statistical Office in Warsaw 2016 - 2018. Author's own calculations.

The randomness study of the distribution of the random component was carried out with the help of a graphical analysis and the test of the number of series, at a significance level of 0.05 . The graphic analysis and the test of the number of series verify the hypothesis and confirm the accuracy of the selection of the analytical form of the models (Table 2 ). The random component normality examination was performed using the Kolomogorov-Liliefors test. The compared values calculated with critical values at the significance level of 0.05 do not defy the hypothesis that the distribution of random components is normal. Autocorrelation was tested using the Durin-Watson test, and no autocorrelation of the random component was found at a significance level of 0.05 . The verification of the homoscedasticity hypothesis of random components was performed by means of the Godfeld-Quandt test. At a significance level of 0.05 , the critical values of the $\mathrm{F}$ Snedecor distribution are greater 
than the calculated ones, however, there are no grounds to reject the hypothesis of homoscedasticity of random components.

\section{Results and Discussion}

Marginal theory can be treated as a borderline case analysis of the inventor's and innovator's activity in relation to entrepreneurship (enterprises) in the Polish industry in the years 2015-2017. The subject of the study are growth models expressed by CobbDouglas-type curvilinear power regression. They have been included in tabular arrangement (in two respective models) in Table 2.

Table 2. Power regressions of the number of enterprises (Y1) against process and product innovation expenditures (X1) and the number of inventions (X2) and the number of patents (X3) in industry in Poland in the years $2015-2017$

\begin{tabular}{|c|c|c|c|c|c|c|c|c|c|}
\hline \multirow[t]{2}{*}{$\mathrm{a}$} & \multicolumn{2}{|c|}{$\begin{array}{l}\text { Regression } \\
\text { coefficient } \\
\text { (parameter) }\end{array}$} & \multicolumn{3}{|c|}{ Standard Error } & \multicolumn{3}{|c|}{ T-Test } & \multirow[t]{2}{*}{$\mathrm{R}^{2}$ Adjusted } \\
\hline & $\mathrm{X} 1$ & $\mathrm{X} 2$ & $a$ & $\mathrm{X} 1$ & $\mathrm{X} 2$ & $a$ & $\mathrm{X} 1$ & $\mathrm{X} 2$ & \\
\hline \multirow{2}{*}{$\begin{array}{l}1.1032 \\
(3.0138)^{*}\end{array}$} & 0.727 & 0.431 & 0.48 & 0.15 & 0.18 & 2.26 & 4.77 & 2.37 & 0.84 \\
\hline & $\mathrm{X} 1$ & X3 & $a$ & $\mathrm{X} 1$ & X3 & $a$ & $\mathrm{X} 1$ & $\mathrm{X} 3$ & \\
\hline $\begin{array}{l}1.4931 \\
(4.4509)^{*}\end{array}$ & 0.798 & 0.295 & 0.50 & 0.12 & 0.11 & 2.99 & 6.70 & 2.58 & 0.85 \\
\hline
\end{tabular}

Source: Statistical yearbook of voivodships. Central Statistical Office in Warsaw 2016 - 2018. Author's own calculations.

* free logarithmised term

The range of the significance level of the parameters: $0.00-0.02$

The data presented in Table 2 show the regression dependence of the number of enterprises (entrepreneurship) (Y1) on the process and product innovation expenditures (activities of innovators) (X1) and the number of inventions (activities of inventors) (X2); and in the second model $\mathrm{Y} 1$, the dependence is measured against $\mathrm{X} 1$ (activities of innovators) and the number of patents (activities of inventors) (X3) in the Polish industry in the years 2015-2017. In both models, the variability in the number of enterprises (entrepreneurship) is explained by the outlays on process and product innovation, the number of inventions and the number of patents generated within the industry: $84 \%$ and $85 \%$, respectively. An explanation of high variability has thus been obtained. The volatility is not explained by the participation of other variables that are not the subject of the study. The strength of the relationship between all variables expressed with the multiple correlation coefficient (R) amounts to $92 \%$ for both models. Regression coefficients (parameters) in both models have standard errors lower than $50 \%$ of their absolute values. The t-test values are several times higher than the absolute values of the regression coefficients, whereby the level of significance of the regression coefficients in both models ranges from 0.00 to 0.02 . A statistical evaluation of the regression coefficients indicates the possibility of their use in the econometric analysis of the enterprise (entrepreneurship) and industrial innovation in Poland in the years 20152017.

Regression coefficients (parameters) which determine the elasticity of the number of enterprises (entrepreneurship) relative to the value of process and product innovation expenditure (innovators 'activities) as well as the number of inventions and the number of patents (innovators' activities) in the industry in the years 2015-2017, are referred to as elasticity coefficients. The elasticity coefficients indicate by how many percentage points the dependent variable (Y1) changes (increases or decreases) when factor $\mathrm{Xj}$ increases by $1 \%$, with the relative stability of the remaining factors. The elasticity of enterprises (entrepreneurship) (Table 2) is higher in relation to innovative process and product expenditure (innovators 'activities) (0.727) than the number of inventions (inventors' activities) (0.431).

This also applies to the second model, whereby the elasticity of enterprises (entrepreneurship) is, however, at its highest in relation to the innovative process and product expenditure (innovators 'activities) (0.798) against the number of patents (inventors' activities). Patents, due to their earlier verification by the patent system, encompass a greater number of original inventions, hence they get strengthened with the expenditure on process 
and product innovation in the process of growth in industry. As evidenced by a comparison of the sum of elasticity in the models, the elasticity of enterprises (entrepreneurship) is higher in the first model by 0.065 . However, upon comparing the elasticity of enterprises with respect to innovative process and product outlays, the elasticity is higher for these enterprises in the second model (0.071). This proves that patents (inventors' activities) significantly increase the activity of innovators in the process of entrepreneurship growth in industry.

Comparison of the overall efficiency parameters (constant terms) in the models prior to their delogarithmising shows that the constant term in the second model is $35.3 \%$ higher. This indicates that the overall efficiency of the number of enterprises (entrepreneurship) shaped by the activities of innovators - and the activities of inventors in the second model - increases entrepreneurship by over a third of its growth (35.3\%). Research shows that patents (inventors' activities) boost the activity of innovators, and simultaneously, the overall effectiveness of entrepreneurship shaped by these activities of innovation. Patents, therefore, significantly complement each other in the overall growth of the product of innovation, which contributes to the stable growth of entrepreneurship and innovation in industry.

The combined incrementation in process and product innovation expenditure (activity of innovators) as well as the number of inventions and the number of patents (activity of inventors) by 10\% increases the number of enterprises (entrepreneurship) by about $11 \%$, in both models. This is more than a proportional augmentation of the number of enterprises (entrepreneurship). The sum of $100 \%$ elasticity indicates that the proportion of process and product innovation outlays (activity of innovators) as well as that of the number of inventions and the number of patents (activity of inventors) in the first model is $63 \%$ and $37 \%$ respectively, and in the second one: $73 \%$ and $27 \%$. Comparing these shares shows that $10 \%$ of the proportion of patents (inventors' activities) is transferred onto the process and product innovation expenditures (innovators' activities) in the increase in the number of enterprises (entrepreneurship) in the second model. This proportion is significant as the number of enterprises (entrepreneurship) shifts its character from supply (patents) to that of demand.

Cobb-Douglas regression analysis allows for a determination of the relationship between the number of enterprises (entrepreneurship) (Y1), the average $(\mathrm{X} / \mathrm{Y} 1)$ and the marginal $(\mathrm{dX} / \mathrm{dY} 1)$ values and the amount of the input of factor $\mathrm{X}$. These relationships have been included in Tables 3, 4, 5 and 6.

Table 3. Marginal and average process and product innovation expenditure in the Polish industry in the years $2015-2017$

\begin{tabular}{|c|c|c|c|}
\hline \multirow{2}{*}{$\begin{array}{c}\text { Number of } \\
\text { enterprises }\end{array}$} & \multirow{2}{*}{$\begin{array}{c}\text { Innovative process and } \\
\text { product expenditures }\end{array}$} & \multicolumn{2}{|c|}{ Innovative process and product expenditures per enterprise: } \\
\cline { 3 - 4 }$(\mathrm{X} 1)$ million PLN & average PLN million & marginal PLN million \\
\hline 4010.93 & 720.90 & 0.1797 & 0.1307 \\
\hline 5773.85 & 1189.90 & 0.2061 & 0.1498 \\
\hline 7351.55 & 1658.90 & 0.2257 & 0.1640 \\
\hline 8810.29 & 2127.90 & 0.2415 & 0.1756 \\
\hline 10183.07 & 2596.90 & 0.2550 & 0.1854 \\
\hline 11489.40 & 3065.90 & 0.2668 & 0.1940 \\
\hline 12742.06 & 3534.90 & 0.2774 & 0.2017 \\
\hline 13950.02 & 4003.90 & 0.2870 & 0.2087 \\
\hline 15119.87 & 4472.90 & 0.2958 & 0.2151 \\
\hline 16256.63 & 4941.90 & 0.3040 & 0.2210 \\
\hline
\end{tabular}

Source: Author's own calculations based on the data presented in tables 1 and 2.

The data presented in Table 3 shows that marginal process and product innovation expenditures (marginal activity of innovators) in their middle range constitute $73 \%$ of the average level centre. This means that the marginal value is approaching the average value at a fast rate. The marginal activity of innovators is growing above the average, which is augmenting at a slower rate, while 
entrepreneurship is incrementing at an increasingly faster pace. These interdependencies are characterised by the first model presented in Table 2 .

Table 4. Marginal and average process and product innovation expenditure in the Polish industry in the years 2015 - 2017 (second regression)

\begin{tabular}{|c|c|c|c|}
\hline \multirow{2}{*}{$\begin{array}{c}\text { Number of } \\
\text { enterprises } \\
\text { (Y1) }\end{array}$} & $\begin{array}{c}\text { Innovative process } \\
\text { and product } \\
\text { expenditures (X1) } \\
\text { million PLN }\end{array}$ & \multicolumn{2}{|c|}{ Innovative process and product expenditures per enterprise: } \\
\cline { 3 - 4 } & 720.90 & average PLN million & marginal PLN million \\
\hline 3911.99 & 1189.90 & 0.1843 & 0.1471 \\
\hline 5835.41 & 1658.90 & 0.2039 & 0.1627 \\
\hline 7607.29 & 2127.90 & 0.2181 & 0.1740 \\
\hline 9279.38 & 2596.90 & 0.2293 & 0.1830 \\
\hline 10878.00 & 3065.90 & 0.2387 & 0.1905 \\
\hline 12419.01 & 3534.90 & 0.2469 & 0.1970 \\
\hline 13912.93 & 4003.90 & 0.2541 & 0.2028 \\
\hline 15367.22 & 4472.90 & 0.2605 & 0.2079 \\
\hline 16787.42 & 4941.90 & 0.2664 & 0.2126 \\
\hline 18177.79 & 0.2719 & 0.2169 \\
\hline
\end{tabular}

Source: Author's own calculations based on the data presented in tables 1 and 2.

As evidenced by the data presented in Table 4 (the second model), the marginal process and product innovation expenditures (marginal activity of innovators) in their middle range constitute $80 \%$ of the average level centre. This means that the marginal value is approaching the average one at an even faster rate. The marginal activity of innovators is growing at an even faster pace than the average activity, which is incrementing more slowly, while entrepreneurship is growing even faster. These interdependencies are characterised by the strengthening of innovators' activities with the activities of inventors by means of patents (Table 2).

Table 5. Marginal and average inventions in the Polish industry in the years 2015 - 2017

\begin{tabular}{|c|c|c|c|}
\hline Number of & Number of & \multicolumn{2}{|c|}{ Number of inventions per enterprise: } \\
\cline { 3 - 4 } & & average number & marginal number \\
\hline 5334.22 & 151.40 & 0.0284 & 0.0122 \\
\hline 6545.46 & 243.40 & 0.0372 & 0.0160 \\
\hline 7515.43 & 335.40 & 0.0446 & 0.0192 \\
\hline 8343.07 & 427.40 & 0.0512 & 0.0221 \\
\hline 9074.39 & 519.40 & 0.0572 & 0.0247 \\
\hline 9735.15 & 611.40 & 0.0628 & 0.0271 \\
\hline 10341.43 & 703.40 & 0.0680 & 0.0293 \\
\hline 10904.07 & 795.40 & 0.0729 & 0.0314 \\
\hline 11430.78 & 887.40 & 0.0776 & 0.0335 \\
\hline 11927.24 & 979.40 & 0.0821 & 0.0354 \\
\hline
\end{tabular}

Source: Author's own calculations based on the data presented in tables 1 and 2.

As indicated by the data presented in Table 5 (the first model), the marginal number of inventions (marginal activity of inventors) in their middle range constitutes $86 \%$ of the average level centre.
This means that the marginal number is approaching the average one at the fastest rate. The marginal activity of inventors is growing at the fastest pace, surpassing the average one, which is growing at the 
slowest rate, while entrepreneurship is incrementing

even faster.

Table 6. Marginal and average patents in the Polish industry in the years 2015 - 2017 (second regression)

\begin{tabular}{|c|c|c|c|}
\hline \multirow{2}{*}{$\begin{array}{c}\text { Number of } \\
\text { enterprises (Y1) }\end{array}$} & $\begin{array}{c}\text { Number of patents } \\
(\mathrm{X} 3)\end{array}$ & \multicolumn{2}{|c|}{ Number of inventions per enterprise: } \\
\cline { 3 - 4 } & 100.00 & 0.0169 & marginal number \\
\hline 5918.37 & 179.00 & 0.0255 & 0.0050 \\
\hline 7027.39 & 258.00 & 0.0330 & 0.0075 \\
\hline 7827.62 & 337.00 & 0.0398 & 0.0097 \\
\hline 8469.41 & 416.00 & 0.0462 & 0.0117 \\
\hline 9012.28 & 495.00 & 0.0522 & 0.0136 \\
\hline 9486.60 & 574.00 & 0.0579 & 0.0154 \\
\hline 9910.17 & 653.00 & 0.0634 & 0.0171 \\
\hline 10294.41 & 732.00 & 0.0688 & 0.0187 \\
\hline 10647.14 & 811.00 & 0.0739 & 0.0203 \\
\hline 10973.96 & & 0.0218 \\
\hline
\end{tabular}

Source: Author's own calculations based on the data presented in tables 1 and 2.

As is to be concluded from the data presented in Table 6 (the second model), the marginal number of patents (marginal activity of inventors) in the centre of their range constitutes $29.5 \%$ of the centre of the level average. This, in turn, means that the marginal number decreases, down to zero, which also causes the average number to fall, albeit at a slower pace; however, entrepreneurship (number of enterprises) is incrementing, but its growth rate tends to zero. This indicates the need to modernise these patents to maintain the level of entrepreneurship in industry, and even so as to increase it.

The above interdependencies are related to the average growth rate of the categories subjected to the study. The regularity of incidence of these categories is expressed by the average growth rate within their range, which indicates the nature of changes occurring in these economic phenomena in the industry (Table 7).

Table 7. Average growth rate of the number of enterprises (Y1) within the range of the value of process and product innovation expenditure (X1) as well as the number of inventions (X2) and the number of patents (X3) within the industry in Poland in the years 2015-2017; \%

\begin{tabular}{|l|c|c|c|c|}
\hline Specification & Table 3 & Table 4 & Table 5 & Table 6 \\
\hline Number of enterprises (Y1) & 16.82 & 18.61 & 9.35 & 7.10 \\
\hline Innovative process and product expenditure X1) & 23.85 & 23.85 & & \\
\hline Number of inventions (X2) & & & 23.05 & \\
\hline Number of patents (X3) & & & & 26.18 \\
\hline $\begin{array}{l}\text { Marginal process and product innovation } \\
\text { expenditure }\end{array}$ & 6.01 & 4.41 & & \\
\hline $\begin{array}{l}\text { Average process and product innovation } \\
\text { expenditure }\end{array}$ & 6.01 & 4.41 & & \\
\hline Marginal number of inventions & & & 12.53 & \\
\hline Average number of inventions & & & 12.53 & \\
\hline Marginal number of patents & & & & 17.82 \\
\hline Average number of patents & & & & 17.82 \\
\hline
\end{tabular}

Source: Author's own calculations based on the data presented in tables 3, 4, 5 and 6 with the help of dynamics with a variable basis and a geometric mean.

The comparison of the data presented in Table 7 indicates that with the same average growth rate of process and product innovation expenditure $(23.8 \%)$ (innovators' activity), the average growth rate of the number of inventions is the same (23\%) (inventors' activity) while that of the number patents is faster 
by 3 percentage points (26\%). This faster average growth rate by 3 percentage points of the number of patents causes the augmentation of the average growth rate of the marginal and average number of patents by over 5 percentage points. This implies a better application of the number of patents in the average industry enterprise over the studied period. Patents as a synthetic (original) category are characterised by better qualitative use within the Polish industry.

At a relatively constant average growth rate of innovators 'activity, one can present the regression dependence of the increase in entrepreneurship (number of enterprises) on the number of patents (inventors' activities). The number of enterprises (entrepreneurship) (Y1) can be expressed by a single-factor Cobb-Douglas power function $(\mathrm{Y} 1=\mathrm{a}$ $\left.* \mathrm{X} 3^{\mathrm{b}}\right)$.

$$
\mathrm{Y} 1=\mathrm{f}(\mathrm{X} 3)
$$

The maximum number of enterprises (entrepreneurship) is achieved when the subsequent increase in patents (dX3) no longer brings an augmentation in the number of enterprises (entrepreneurship). This dependency is expressed by the following formula:

$$
\mathrm{dX} 3 / \mathrm{dY} 1=0
$$

The industry is interested in whether the cost (expenditure expressed in monetary means) of subsequent patents will bring an additional effect of entrepreneurship (number of enterprises). This answer can be obtained using the marginal calculus. If the growth in entrepreneurship is presented as the cost of the number of patents $\left(\mathrm{P}_{\mathrm{Y} 1}\right)$, similarly to the cost of the number of patents $\left(\mathrm{P}_{\mathrm{X} 3}\right)$, then the optimal level of patent implementation can be determined. It is equal to the next number of patents that brings an increase in entrepreneurship (number of enterprises), which in turn is equal to the cost value of the number of patents. Further patent expansion in the same market conditions is no longer justified as it results in a decline in entrepreneurship (number of enterprises). This interdependency can be expressed as follows:

$$
(\mathrm{dX} 3 / \mathrm{dY} 1) * \mathrm{P}_{\mathrm{Y} 1}=\mathrm{P}_{\mathrm{X} 3}
$$

The marginal calculus serves to optimise the number of patents, and it is more complex, as the effects of patents last for several years.

\section{Conclusion}

Entrepreneurship and innovation - understood as a process of creation and growth of enterprises constitute an instrument of structural transformation in the innovative economy. The theory of cumulative changes serves well to elucidate the process of establishing entrepreneurship with the participation of innovations. It explains the dependence of positive feedbacks in that a change of one factor strengthens the impulses that stimulate the change retroactively. There are two ways in which innovation can be introduced to industry: the market and the institutional type of introduction.

The research has confirmed the hypothesis that patents as a result of the inventors' activities strengthen themselves together with the process and product innovation expenditures (activities of innovators) over the course of the process of increasing entrepreneurship (enterprises) of industry, while also boosting the overall efficiency of these expenditures and technologies (patents) in the Polish industry over the researched period.

The conducted studies have shown that entrepreneurship (the number of enterputises) relative to innovative process and product inputs (innovators 'activities), as well as inventions and patents (inventors' activities), increases more than proportionally in the years studied. It turned out that patents (inventors 'activities) supplemented the share (elasticity) of innovative process and product expenditures (innovators' activities) by $10 \%$ in the increase in the number of enterprises (entrepreneurship) that emerged in (the industry. This share is transferred from the supply type to the demand one. This proves that these activities are mutually complementary in the process of economic growth.

Comparisons of the impact of inventions and patents in separate models on the increase in entrepreneurship (number of enterprises) show that the formation of the marginal number category of patents and inventions is different for the same period of research. It has been explained that when the marginal number of patents decreases, it causes their average number to decrease, while the number of enterprises (entrepreneurship) is on the rise, although its growth rate tends to zero. Nonetheless, the category of inventions does not specify this last important interdependency. It is of high significance as it explains that the wave of entrepreneurship growth closes within the three years undider review, and thus the activity of innovators will be on the decrease. This is consistent with the fluctuation in Schumpeter's theory. The patent category as a synthetic one describes precisely the variability of entrepreneurship (number of enterprises). It indicates the necessary secondary entrepreneurship with the help of innovation (patents) in industry. 
The conducted research has shown that the integration of knowledge and its commercialisation are separate activities of inventors and innovators, which strengthen themselves mutually in the process of economic growth.

\section{References:}

[1] Duan, X. Systematic Risk Measurement Based on CoVaR Model. International journal of circuits, systems and signal processing, Vol. 13, 2019, pp. 243-250.

[2] Hughes, A. \& Mina, A. The Impact of the Patent System on SMEs. Working Papers wp411, Centre for Business Research, University of Cambridge 2010.

[3] Bessen, J., \& Maskin, E. Sequential innovation, patents, and imitation. RAND Journal of Economics, Vol. 40, No. 4, 2009, pp. 611-635.

[4] Hu, A. G., \& Jefferson, G. H. A great Wall of patents: What is behind China's recent patent explosion? Journal Development Economics, Vol. 90, No. 1, 2009, pp. 57-68.

[5] Sharma, R., Paswan, A. K., Ambrammal, S. K., \& Dhanora, M. Impact of patent policy changes on $\mathrm{R} \& \mathrm{D}$ expenditure by industries in India. Journal World Intellectual Property, Vol. 21, No, (1-2), 2018. pp. 52-69.

[6] Horner, R. The Impact of Patents on Innovation, Technology Transfer and Health: A Pre-and Post-TRIPs Analysis of Indiae's Pharmaceutical Industry. New Political Economy, Vol. 19, No. 3, 2014. pp. 384-406.

[7] Haeussler, C., Harhoff, D., \& Müller, E. To be financed or not - the role of patents for venture capital financing. Munich School of Management Discussion Paper 09-003, 2009.

[8] Gans, J., Hsu, D., \& Stern, S. The impact of uncertain intellectual property rights on the market for ideas: evidence from patent grant delays. Management Science, Vol. 54, 2008, pp. 982-997.

[9] Hall, B. H. Business and financial method patents, innovation, and Policy. NBER Working Paper n 14868, 2009.

[10] Breiteman, A., \& Hicks, D. An Analysis of Small Business Patents by Industry and Firm Size. Faculty Scholarshipfor the College of Science \& Mathematics, 12, 2008.
The empirical research undertaken in the future will focus on the further exploration of the interdependency of the categories of effects of inventions and innovators and their optimisation, so as to offer a superior explanation of the issue of implementing innovation in industry.

[11] Ahead, R., \& Ghosh, A. Business Method Patents. Journal of Intellectual Property Rights, Vol. 11, 2006, pp. 175-184.

[12] Boldrin, M., \& Levine, D. K. The Case Against Patents. Working Paper 2012-035A. 2012.

[13] Ivus, O. Does stronger patent protection increase export variety? Evidence from US product-level data. Journal of International Business Studies, Vol. 46, No. 6, 2015, pp. 724-731.

[14] Serrano, C. J. The Dynamics of the Transfer and Renewal of Patents. NBER Working, no.13938. 2008.

[15] Williams, H. L. How do patents affect research investment? Annual Review of Economics, Vol. 9, 2017, pp. 441-469.

[16] Estèves, N. 2018. Open models for patents: Giving patents a new lease on life? Journal World Intellectual Property, Vol. 21, No. 1-2, 2018, pp. 2-14.

[17] Levitas, E., \& McFadyen, M. A. Managing liquidity in research-intensive firms: Signaling and Cash flow effects of patents and Alliance activities. Strategic Management Journal, Vol. 30, No. 6, 2009, pp. 659-678.

[18] Roin, B. The case for tailoring patent awards based on time-to-market. UCLA Law Review, Vol. 61, No. 3, 2014, pp. 672-759.

[19] Janger, J., Schubert, T., Andries, P., Rammer, C., \& Hoskens, M. The EU 2020 innovation indicator: A step forward in measuring innovation outputs and outcomes? Research Policy, Vol. 46, No. 1, 2017, pp. 30-42

[20] Raghupathi, V., \& Raghupathi, W. Exploring science-and-technology-ledinnovation: a cross-country study. Journal of Innovation and Entrepreneurship, Vol. 8, article 5, 2019.

[21] Carbone, P. Acquisition Integration Models: How LargeCompanies Successfully Integrate Startups. Technology Innovation Management Review, Vol. 1, No. 1, 2011, pp. 26-31,

[22] Chang, S.-J., \& Wu, B. 2014. Institutional Barriers and Industry Dynamics. Strategic 
Management Journal, Vol. 35, 2014, pp. 1103-1123.

[23] Bao, G., Zeng, F., \& Wang, M. Study on human resource allocation efficiency based on DEA analysis. International journal of circuits, systems and signal processing, vol. 14, 2020, pp. 826-832,

[24] de Wilton, A. Patent Value: A Business Perspectivefor Technology Startups. Technology Innovation Management Review. Vol. 1, No. 3, 2011, pp. 5-11.

[25] Sierotowicz, T. Patent activity as an eff ect of the research and development of the business enterprise sectors in the countries of the European Union. Journal of International Studies, Vol. 8, No. 2, 2015, pp. 101-113.

[26] Demir, C. 2019. Private or Universities? The Effectiveness of R\&D Efforts in OECD Countries. Ekonomski Pregled, Vol. 70, No. 2, pp. 276-300,

[27] Raffoul, N., \& Brion, A. Reasons for Patent Protection and Cost-effective Patent Filing Options for SMEs. Technology Innovation Management Review. December 2011, pp.2933.

[28] Singh, S. 2018. Patenting Matters, Not Patents: Firm Market Value in Indian Manufacturing. The Journal of Applied Economic Research, 12(1), 67-87,

[29] Dou, H., \& Hongxia, X. 2012 The role of Patent Information in the development of Innovation in SMEs - A focus on Chinese patent. Revue internationale d'intelligence économique, Vol. 2, No. 4), 2012, pp. 187203.

[30] Jewik, P. The Utility Model-An Effective Tool in Global Patent Portfolio Protection, Intellectual Property today, 2010, pp. 20-21.

[31] Dombrachev, A. N., Yakimovich, B. A., Korshunov, A. I., \& Solomennikova, S. I. Patent Activity of High-Tech Enterprisesin the Republic of Udmurtia. Russian Engineering Research, Vol. 36, No. 7, 2016, pp. 573-576.

[32] Raghupathi, V., \& Raghupathi, W. Innovation at country-level: association-between economic development and patents. Journal of Innovation and Entrepreneurship, Vol. 6, article 4, 2017.

[33] Al.-Mubaraki, H., \& Busler, M. Road Map of International Business Incubation Performance. Journal of International
Business and Cultural Studies, Vol. 6, 2012, pp.1-15,

[34] Al.-Mubaraki, H., \& Aruna, M. Technology Innovation for SME Growth: A Perception for the Emerging Economies. Journal of Economics and Sustainable Development, Vol. 4, No. 3, 2013, pp. 153-163.

[35] Luo, Y., T., Liang, Z., Du, X. I., \& Xia, D. 2016. Study on the Cumulative Innovation Effect of the Competitive Patent Pools Based on the Different Technical Standards. Open Journal of Business and Management, Vol. 4, 2016, 445-460,

[36] Moser, P., \& Lampe, R. L. 2012. Do Patent Pools Encourage Innovation? Evidence from 20 U.S. Industries Under the New Deal. Working Paper No. 524.

[37] Galasso, A., \& Schankerman, M. Patents and cumulative innovation: causa evidence from the courts. Quarterly Journal of Economics, Vol. 130, No. 1, 2014, pp. 317-369.

[38] Ferraro, S., Dutt, P. K., \& Kerikmae, T. Using Patent Development, Education Policy and Research and Development Expenditure Policy to Increase Technological Competitiveness of Small European Union Member States. Croatian International Relations Review, Vol. 23, No. 78, 2017, pp. 97-126.

[39] Landers, A. L. The Interconnections between Entrepreneurship, Science, and the Patent System. Utah Law Review, Vol.4, 2016, pp. 630-660.

[40] Hausmann, R. Hidalgo, C. A., Stock, D. P., \& Yildirim, M. A. Implied Comparative Advantage. Harvard Kennedy School, Working Paper No. RWP14-003. 2014.

[41] Serrano, C. The Market for Intellectual Property: Evidence from the Transfer of Patents. Working Paper, University of Toronto. 2006.

[42] Acs, Z., \& Sanders, M. Patents, Knowledge Spillovers, and Entrepreneurship. Small Business Economics, Vol. 39, No. 4, 2012, pp. 801-817.

[43] Guloglu, B., \& Tekin, R. B. A panel causa lity analysis of the relationship among research and development, innovation, and economic growth in highincome OECD countries. 
Eurasian Economic Review, Vol. 2, No. 1, 2012, pp. 32-47.

[44] Triola, M. Essentials of Statistics. London: Pearson. 2014.

[45] van Praag, C. M., \& Versloot, P. H. What is the value of entrepreneurship? A review of recent research. Small Business Economics Vol. 29, 2007, pp. 351-382.

\section{Creative Commons Attribution License 4.0}

(Attribution 4.0 International, CC BY 4.0)

This article is published under the terms of the Creative Commons Attribution License 4.0

https://creativecommons.org/licenses/by/4.0/deed.e n_US 